\title{
Metode Monitoring Resistensi Populasi Aedes aegypti Dengan Penetapan Konsentrasi Diagnostik
}

\author{
Vicka Kusuma Sari, Udi Tarwotjo dan Mochamad Hadi \\ Laboratorium Biologi Struktur dan Fungsi Hewan, Departemen Biologi, Fakultas Sains dan Matematika, \\ Universitas Diponegoro Jl. Prof. H. Sudharto, Tembalang, Semarang. \\ Email:vicka070195@gmail.com
}

\begin{abstract}
Aedes aegypti is the main vector of dengue fever disease. The most effective way to prevent dengue fever is cutting the spreading chain of dengue fever by controlling the vector with using conventional chemical insecticides. The used of insecticide intensively has became the main factor of resistance in Tembalang, then monitoring is needed to determine the change of $A$. aegypti susceptibility status against the insecticide. The aim of this research is to determine the sensitivity of A. aegypti population from five locations in Tembalang against pyrethroid synthetic insecticide, and to determine the validity of the diagnostic concentration as a method of monitoring resistance $A$. aegypti population in Tembalang. This research was conducted in Laboratory of Ecology and Biosystematics Department of Biology Faculty of Science and Mathematics, Diponegoro University Semarang. The procedure of this research were: larvae collection (A. aegypti), insect breeding test, sensitivity test including bioassay, determination of diagnostic concentration and validation. The result showed that the susceptibility level of five population was not significantly different since all populations are still susceptible, with the $\mathrm{LC}_{50}$ range between $0,0031-0,0043 \%$ and FR range between 1-1,39 $(<4)$. The result of validation test of diagnostic concentration was $0,0038 \%$, valid as a monitoring method of the resistance of $A$. aegypti population against pyrethroid synthetic insecticide in Tembalang because $\chi^{2}$ value of the five population was lower than the $\chi^{2}$ table $(\mathrm{df}=1 ; \alpha=0,05)=$ 3,84 .
\end{abstract}

Keywords : A. aegypti, monitoring resistance, $L C_{50}$, diagnostic concentration..

\begin{abstract}
Abstrak
Aedes aegypti merupakan vektor utama penyakit demam berdarah dengue (DBD). Solusi yang paling efektif untuk penanggulangan dan pencegahan DBD adalah pemutusan rantai penularan melalui pengendalian vektornya dengan memanfaatkan insektisida kimia konvensional. Penggunaan insektisida secara intensif diduga menjadi salah satu faktor penyebab terjadinya resistensi, sehingga perlu adanya monitoring untuk mengetahui perubahan status kerentanan populasi A. aegypti terhadap insektisida. Tujuan penelitian ini adalah untuk mengetahui tingkat kepekaan populasi A. aegypti dari lima lokasi di Kecamatan Tembalang terhadap insektisida piretroid sintetik dan menetapkan validitas konsentrasi diagnostik sebagai metode monitoring resistensi populasi A. aegypti di Kecamatan Tembalang. Penelitian dilaksanakan di Laboratorium Ekologi dan Biosistematik Departemen Biologi Fakultas Sains dan Matematika Universitas Diponegoro. Prosedur penelitian ini yaitu: koleksi larva A. aegypti, pembiakan serangga uji, pengujian kepekaan berupa uji bioassay, penetapan konsentrasi diagnostik, dan validasi. Hasil penelitian menunjukkan bahwa tingkat kepekaan dari lima populasi tersebut tidak berbeda nyata karena semua populasi masih peka, dengan nilai $\mathrm{LC}_{50}$ berkisar antara 0,0031-0,0043\% dan FR berkisar antara 1-1,39 $(<4)$. Hasil pengujian validasi konsentrasi diagnostik sebesar $0,0038 \%$, valid sebagai metode monitoring resistensi populasi A. aegypti terhadap insektisida piretroid sintetik di Kecamatan Tembalang karena nilai $\chi^{2}$ hitung kelima populasi yang diuji lebih kecil dari nilai $\chi^{2}$ tabel yaitu $(\mathrm{df}=1 ; \alpha=0,05)=3,84$
\end{abstract}

Kata kunci : A. aegypti, monitoring resistensi, $L C_{50}$, konsentrasi diagnostik.

\section{PENDAHULUAN}

Kecamatan Tembalang merupakan wilayah endemis DBD dengan angka kesakitan (incidence rate) IR DBD paling tinggi di Kota Semarang pada tahun 2016 (IR = 70,48/100.000 penduduk). Demam berdarah dengue/DBD adalah penyakit 
infeksi yang disebabkan oleh virus dengue (Suhendro dkk, 2006). Penularan infeksi virus dengue terjadi melalui vektor nyamuk genus Aedes terutama nyamuk A. aegypti. Penyakit DBD setiap tahunnya menjadi penyakit dengan angka kematian tertinggi. Sampai saat ini obat untuk pengobatan DBD maupun vaksin untuk mencegahnya belum ditemukan dan pengendalian vektor merupakan cara untuk memutus rantai penularannya (Achmadi, 2010).

Pengendalian vektor di Indonesia masih bergantung pada pengendalian secara kimiawi menggunakan insektisida (Yuniarti dan Damar, 2008). Berdasarkan hasil wawancara masyarak di lima Kelurahan di Kecamatan Tembalang yaitu Kelurahan Sendangmulyo, Meteseh, Tandang, Sendangguwo dan Tembalang masih memanfaatkan insektisida kimia konvensional, seperti golongan piretroid sintetik. Aplikasi insektisida golongan piretroid sintetik berupa obat semprot digunakan oleh masyarakat secara intensif. Penggunaan insektisida golongan piretroid sintetik yang intensif diduga menjadi salah satu faktor penyebab terjadinya resistensi (Shelton et al., 2000), sehingga perlu adanya metode monitoring resistensi untuk meilhat adanya perubahan status kerentanan suatu populasi vektor terhadap insektisida. Metode monitoring resistensi biasanya dilakukan secara konvensional dengan 45 seri konsentrasi untuk mendapatkan nilai Lethal Dose (LD) atau Lethal Concentrasion (LC). Namun metode ini kurang peka terhadap peristiwa resistensi yang baru muncul, sehingga dikembangkan metode monitoring yang lebih sensitif terhadap perubahan kecil frekuensi resistensi, yaitu dengan menggunakan konsentrasi diagnostik (Halliday \& Burnharm 1990; Untung, 2004) untuk melihat status kerentanan nyamuk $A$. aegypti di Kecamatan Tembalang.

Masalahnya adalah apakah populasi $A$. aegypti yang diuji dari lima lokasi di Kecamatan Tembalang telah resisten terhadap insektisida golongan piretroid sintetik. Konsentrasi diagnostik yang diperoleh tersebut valid atau tidak untuk metode monitoring resistensi populasi $A$. aegypti terhadap insektisida golongan piretroid sintetik di Kecamatan Tembalang. Oleh karena itu perlu dilakukan penelitian untuk mengetahui tingkat kepekaan populasi $A$. aegypti dari lima Kelurahan di Kecamatan Tembalang terhadap insektisida piretroid sintetik dan valid tidaknya konsentrasi diagnostik yang diperoleh sebagai metode monitoring resistensi populasi A. aegypti terhadap insektisida uji di Kecamatan Tembalang

\section{BAHAN DAN METODE \\ Koleksi Larva $A$. aegypti}

Koleksi larva $A$. aegypti dilakukan di lima Kelurahan di Kecamatan Tembalang yaitu Kelurahan Tembalang, Meteseh, Sendangmulyo, Sendangguwo, dan Tandang. Koleksi larva ini menggunakan ovitrap dan mengambil larva langsung dari bak kamar mandi maupun tempat penampungan air di rumah warga.

\section{Pembiakan Serangga Uji}

Pembiakan ini dilakukan di kandang nyamuk berukuran $40 \mathrm{~cm} \mathrm{x} 40 \mathrm{~cm}$ yang terbuat dari kayu dan sisinya ditutup menggunakan kain tile. Nyamuk betina dewasa diberi pakan berupa darah dari marmut yang telah dicukur rambutnya. Nyamuk betina dewasa ini diberi makan pada pagi dan sore hari selama 1 jam. Sedangkan untuk pakan nyamuk jantan dewasa menggunakan bolabola kapas yang telah dicelupkan ke larutan gula $100 \%$.

Uji Kepekaan Populasi A. aegypti terhadap Insektisida Piretroid Sintetik

Pengujian kepekaan ini dilakukan dengan uji hayati (bioassay) dalam 2 tahapan. Tahapan pertama adalah uji pendahuluan yang bertujuan untuk mendapatkan working concentration untuk menentukan nilai batas atas dan batas bawah bawah. Tahapan kedua adalah uji utama untuk mengestimasi nilai $\mathrm{LC}_{50}-72$ jam dari lima populasi uji menggunakan analisis probit (Finney, 1971). Untuk setiap konsentrasi perlakuan digunakan 10 ekor larva instar III yang dimasukkan kedalam gelas berisi $100 \mathrm{ml}$ larutan dengan berbagai konsentrasi perlakuan. Perhitungan tingkatan konsentrasi untuk uji utama berdasarkan formulasi Hubert (1997 dalam Widyastuti, 1999).

\section{Penetapan Konsentrasi Diagnostik}

Penentuan konsentrasi didasarkan pada hasil pengujian kepekaan suatu populasi serangga terhadap insektisida tertentu. Data yang didapatkan hasil analisis probit pada uji utama dari lima populasi di Kecamatan Tembalang dilihat status 
resistensinya. Populasi yang memiliki data mortalitas dengan status resistensi yang masih peka dan mempunyai $\chi^{2}$ hitung $<\chi^{2}$ tabel dipilih untuk penetapan konsentrasi diagnostik.

\section{Validasi Konsentrasi Diagnostik}

Konsentrasi diagnostik diujikan ke lima populasi selain populasi yang telah digunakan pada uji utama. Pengujian dilakukan dengan larutan insektisida konsentrasi anjuran 0,225\% bahan aktif dan konsentrasi diagnostik yang telah diperoleh, serta control menggunakan etanol. Validasi lapangan ditentukan dengan menghitung:

\section{$\chi^{2}=(\text { observed-expected })^{2} /$ expected ${ }^{2}$}

Konsentrasi diagnostik valid apabila $\chi^{2}$ hitung $<\chi^{2}$ tabel pada $\alpha=0,05$ dengan derajat bebas $=1$ (Trisyono dan Whalon, 1999).

\section{Analisis Data}

Analisis data dilakukan dengan menggunakan analisis probit (Finney, 1971) dengan prosedur dari Busvine (1971) untuk mendapatkan nilai $\mathrm{LC}_{50}$ yang diikuti oleh nilai fiducial limit (FL). Menurut Litchfield dan Wilcoxon (1949) dalam Ullah dan Shad (2017), nilai $\mathrm{LC}_{50}$ berbeda nyata apabila nilai FLnya tidak saling tumpang tindih.

\section{HASIL DAN PEMBAHASAN}

Uji Kepekaan Populasi A. aegypti terhadap Insektisida Piretroid Sintetik Uji Pendahuluan

Hasil uji pendahuluan menggunakan konsentrasi anjuran dapat dilihat pada Tabel 1 . Konsentrasi anjuran yang digunakan masih banyak menghasilkan mortalitas $100 \%$ karena konsentrasi anjuran $0,225 \%$ bahan aktif digunakan untuk nyamuk dewasa, sedangkan pada uji pendahuluan ini menggunakan larva, sehingga konsentrasi pada uji pendahuluan perlu diturunkan. Pada Tabel 1 tersebut menunjukkan bahwa jumlah larva uji yang mati sampai konsentrasi $0,0281 \%$ lebih dari $90 \%$, sehingga batas atas tidak terpenuhi, karena itu tingkatan konsentrasi uji perlu diperkecil, yaitu $0,0281 \%, \quad 0,0141 \%, 0,0070 \%, 0,0035 \%$ dan $0,0018 \%$.
Tabel 1. Hasil Uji Pendahuluan Menggunakan Konsentrasi Anjuran

\begin{tabular}{llll}
\hline $\begin{array}{l}\text { Konsentrasi } \\
(\%)\end{array}$ & $\begin{array}{l}\text { Total } \\
\text { Larva Uji } \\
\text { (individu) }\end{array}$ & $\begin{array}{l}\text { Jumlah } \\
\text { Serangga } \\
\text { Mati } \\
\text { (individu) }\end{array}$ & $\begin{array}{l}\text { Persentase } \\
\text { Kematian } \\
(\%)\end{array}$ \\
\hline 0,225 & 10 & 10 & 100 \\
0,1125 & 10 & 10 & 100 \\
0,0563 & 10 & 10 & 100 \\
0,0281 & 10 & 10 & 100 \\
0,0141 & 10 & 5 & 50 \\
0 & 10 & 0 & 0 \\
\hline
\end{tabular}

Tabel 2. Hasil Uji Pendahuluan Setelah Konsentrasi Diperkecil

\begin{tabular}{llll}
\hline $\begin{array}{l}\text { Konsentrasi } \\
(\%)\end{array}$ & $\begin{array}{l}\text { Total } \\
\text { Larva Uji } \\
\text { (individu) }\end{array}$ & $\begin{array}{l}\text { Jumlah } \\
\text { Serangga } \\
\text { Mati } \\
\text { (individu) }\end{array}$ & $\begin{array}{l}\text { Persentase } \\
\text { Kematian } \\
(\%)\end{array}$ \\
\hline 0,0281 & 10 & 10 & 100 \\
0,0141 & 10 & 9 & 90 \\
0,0070 & 10 & 4 & 40 \\
0,0035 & 10 & 4 & 40 \\
0,0018 & 10 & 5 & 50 \\
0 & 10 & 0 & 0 \\
\hline
\end{tabular}

Hasil uji pendahuluan ini pada pengamatan ke-24 jam sudah ada konsentrasi yang dapat mematikan semua larva uji, sehingga uji pendahuluan dapat dihentikan. Pada tabel tersebut menunjukkan bahwa jumlah larva uji yang mati pada konsentrasi tertinggi lebih dari $90 \%$ dari jumlah larva uji, sehingga konsentrasi yang dijadikan batas atas adalah $0,0141 \%$ dan sebagai batas bawah adalah 0,0018\%. Mortalitas pada konsentrasi $0,0018 \%$ lebih besar dibandingkan dengan konsentrasi $0,0035 \%$, mungkin dapat disebabkan karena daya tahan tiap individu spesies tersebut berbeda-beda. Setelah batas atas dan bawah ditentukan, kemudian dibuat lima tingkatan konsentrasi uji berdasarkan batas-batas tersebut dengan menggunakan rumus Hubert (1979) ditambah perlakuan kontrol. Tingkatan lima konsentrasi ini digunakan dalam pengujian utama

\section{Uji Utama}

Tingkatan konsentrasi yang diperoleh dari rumus Hubert untuk uji utama yaitu $0,0128 \%, 0,0087 \%, 0,0059 \%, 0,0040 \%$ dan 
$0,0027 \%$, namun masih ada yang mematikan $100 \%$ dan tidak dapat dihitung dengan analisis probit (Finney, 1971) sehingga konsentrasi yang digunakan diturunkan menjadi $0,0064 \%$, $0,0044 \%, 0,0030 \%, 0,0020 \%$ dan $0,0014 \%$.

Hasil analisis probit uji utama menunjukkan bahwa $\mathrm{LC}_{50}$ dari kelima populasi di Kecamatan Tembalang berkisar antara 0,0031-0,0043\%. Populasi di Kelurahan Tembalang memiliki nilai $\mathrm{LC}_{50}$ yang paling rendah dan menunjukkan tidak berbeda nyata dengan populasi Kelurahan Tandang, Sendangmulyo, Sendangguwo, dan Meteseh, dimana batas atas dan batas bawahnya saling tumpang tindih (overlap). Huruf yang dicetak sesuai notasi (a, b, c, d) pada $\mathrm{LC}_{50}$ menyatakan tingkat signifikasinya pada taraf $\alpha=$ 0,05. Apabila nilai $\mathrm{LC}_{50}$ diikuti dengan huruf yang sama menunjukkan bahwa populasi tersebut tidak berbeda nyata. Hal ini sesuai dengan pendapat dari Negara (2003) nilai $\mathrm{LC}_{50}$ yang diikuti huruf yang sama tidak berbeda nyata karena batas bawah dan batas atas nilai $95 \%$ selang kepercayaan (SK) saling tumpang tindih. Hasil analisis probit uji utama dari lima populasi dapat dilihat pada Tabel 3.

Tingkat kepekaan populasi A. aegypti dari lima lokasi pengujian ini berdasarkan dari perhitungan faktor resistensi (FR). Faktor resistensi didapatkan dari perbandingan antara $\mathrm{LC}_{50}$ populasi uji dengan nilai $\mathrm{LC}_{50}$ terendah. Hasil Tabel 3 menunjukkan bahwa Populasi Kelurahan Tembalang merupakan populasi yang faktor resistensinya terendah karena memiliki nilai $\mathrm{LC}_{50}$ yang paling kecil. Oleh karena itu nilai $\mathrm{LC}_{50}$ populasi Kelurahan Tembalang dijadikan sebagai pembanding untuk menentukan faktor resistensi populasi A. aegypti dari kelima populasi yang diuji menggunakan insektisida piretroid sintetik.
Menurut Untung (2004) populasi dengan nilai $\mathrm{LC}_{50}$ paling rendah merupakan populasi paling peka, dan tingkat kepekaan satu populasi terhadap populasi lainnya dibandingkan dengan menghitung faktor resistensi.

Populasi Kelurahan Tandang memiliki FR dan nilai $\mathrm{LC}_{50}$ yang paling tinggi diantara yang lain namun jika dilihat dari nilai FRnya, populasi Tandang termasuk populasi yang masih peka karena nilai FRnya kurang dari 4. Menurut Winteringham (1969) bahwa suatu populasi dikatakan telah resisten terhadap suatu insektisida tertentu, jika suatu populasi faktor resistensinya $\geq$ 4. Tinggi rendahnya nilai FR disebabkan perilaku masyarakat dalam mengendalikan vektor demam berdarah yaitu $A$. aegypti dengan insektisida, seperti frekuensi penyemprotan dan jenis insektisida yang digunakan 
Tabel 3. Hasil Analisis Probit Uji Utama dari Lima Populasi di Kecamatan Tembalang

\begin{tabular}{cccccccc}
\hline No & Populasi & N & $\begin{array}{c}\text { Mortalitas } \\
\text { Kontrol }\end{array}$ & Slope & $\begin{array}{c}\text { LC }_{50} \\
(\%)\end{array}$ & FR & $\chi^{2}$ \\
\hline 1 & Tembalang & 30 & 0 & 3,35 & $0,0031(0,0021-0,0038) \mathrm{a}$ & 1 & 6,65 \\
2 & Sendangguwo & 30 & 0 & 3,04 & $0,0033(0,0022-0,0042) \mathrm{a}$ & 1,06 & 2,33 \\
3 & Sendangmulyo & 30 & 0 & 3,27 & $0,0036(0,0023-0,0053) \mathrm{a}$ & 1,17 & 0,84 \\
4 & Meteseh & 30 & 0 & 2,72 & $0,0039(0,0024-0,0059) \mathrm{a}$ & 1,27 & 0,29 \\
5 & Tandang & 30 & 0 & 3,90 & $0,0043(0,0036-0,0049) \mathrm{a}$ & 1,39 & 6 \\
\hline
\end{tabular}

Larva yang digunakan adalah larva instar $3 ; \mathrm{LC}_{50}$ yang diikuti dengan huruf yang sama tidak berbeda nyata; $\mathrm{FR}=$ faktor resistensi; Nilai $\chi^{2}$ tabel $(\mathrm{df}=3 ; \alpha=0,05)=7,81$

Hasil analisis probit uji utama (Tabel 3) dari kelima populasi menunjukkan bahwa kelima populasi ini bersifat homogen dimana nilai $\chi^{2}$ hitung kurang dari $\chi^{2}$ tabel, dimana $\chi^{2}$ tabel untuk derajat bebas $3(\alpha=0,05)$ adalah 7,81. Berdasarkan pendapat Umniyati (1990), nilai $\chi^{2}$ hasil perhitungan apabila lebih kecil dari nilai $\chi^{2}$ tabel, maka percobaan bersifat homogen.

Berdasarkan nilai kemiringan (slope) terhadap d-fenotrin dan prallethrin, bahwa populasi A. aegypti yang dikoleksi dari lima populasi, nilai kemiringannya berkisar antara 2,723,90. Populasi Meteseh mempunyai nilai kemiringan paling kecil yang menunjukkan bahwa tingkat heterogenitasnya tinggi. Populasi heterogen menunjukkan adanya keragaman tanggapan populasi terhadap insektisida dan apabila populasi tersebut diberi tekanan seleksi terus menerus dengan jenis insektisida yang sama atau insektisida berbeda dengan bahan aktif yang sama akan menyebabkan populasi berpotensi berkembang menjadi populasi yang resisten. Populasi yang nilai kemiringannya besar, menunjukkan tanggapan populasi $A$. aegypti terhadap obat nyamuk semprot yang berbahan aktif d-fenotrin dan prallethrin bersifat homogen yang berarti tidak ditemukan adanya keragaman tanggapan populasi terhadap insektisida dan terdiri dari individu dengan tingkat resistensi yang sama (Kerns et al, 1998).

\section{Penetapan Konsentrasi Diagnostik}

Penetapan konsentrasi diagnostik ini berkaitan dengan hasil uji kepekaan suatu populasi dari uji utama. Dari hasil analisis probit uji utama menunjukkan bahwa kelima populasi yang diuji semuanya masih peka dan mempunyai $\chi^{2}$ hitung < $\chi^{2}$ tabel yang berarti data tersebut bersifat homogen, sehingga kelima populasi ini digunakan untuk penentuan konsentrasi diagnostik. Hal ini sesuai dengan pernyataan Marcon et al (2000), populasi-populasi yang hasil pengujian kepekaannya mempunyai nilai $\chi^{2}$ hitung $<\chi^{2}$ tabel digunakan untuk penentuan konsentrasi diagnostik. Hasil data mortalitas dari uji penetapan konsentrasi diagnostic ini diestimasi nilai $\mathrm{LC}_{50}$ nya dengan analisis probit (Finney, 1971).

Kelima populasi ini digunakan dalam penetapan konsentrasi diagnostik dengan cara memelihara jentik dari lima populasi dalam satu kandang sehingga pada saat dewasa bisa menghasilkan keturunan F1 dari lima populasi tersebut. Konsentrasi yang digunakan dalam penetapan konsentrasi diagnostik adalah konsentrasi $\quad 0,0064 \%, \quad 0,0044 \%, \quad 0.0030 \%$, $0.0020 \%$, dan $0,0014 \%$.

Hasil dari analisis probit $\mathrm{LC}_{50}$ yaitu konsentrasi diagnostik yang didapatkan adalah $\mathrm{LC}_{50}=0,0038 \%$ dengan batas konsentrasi terendah $0,003 \%$ dan tertinggi $0,0047 \%$. Berdasarkan hasil pengujian kepekaan semua populasi yang diuji masih peka terhadap insektisida piretroid sintetik dari obat nyamuk yang digunakan dengan mortalitas $>86 \%$ pada konsentrasi $0,0064 \%$. Apabila konsentrasi diagnostik memakai konsentrasi anjuran maupun konsentrasi 0,0281\%, maka dapat menyebabkan mortalitas $100 \%$ sehingga tidak akan peka terhadap perubahan kecil frekuensi resistensi.

Hasil penelitian Mascarenhas dan Boethel (2000) menunjukkan bahwa konsentrasi diagnostik $1.300 \mathrm{ppm}$ insektisida piretroid sintetik yaitu permethrin yang diujikan kepada larva Pseudoplusia includes memiliki persentase 
kelangsungan hidup yang rendah dimana persentase kematiannya $>80 \%$ populasi peka yang terpapar insektisida dan $<20 \%$ membunuh serangga pada populasi resisten. McCutchen (1989) juga melaporkan dengan menggunakan monitoring diagnostik diketahui bahwa larva Heliothis zea menunjukkan mortalitas 93-100\% terhadap insektisida golongan piretroid sintetik yaitu cypermethrin.

Tabel 4. Hasil Validasi Konsentrasi Diagnostik untuk Kepekaan Populasi Aedes aegypti terhadap Insektisida Piretroid Sintetik

\begin{tabular}{lllcccc}
\hline No & \multicolumn{1}{c}{ Populasi } & Kecamatan & $\begin{array}{c}\text { Harapan } \\
\text { Kematian } \\
(\%)\end{array}$ & $\begin{array}{c}\text { Moratalitas Terkoreksi (\%) } \\
\left(\mathrm{LC}_{50}=0,0038 \%\right)\end{array}$ & $\begin{array}{c}\chi^{2} \\
\text { hitung }\end{array}$ & $(0,225 \% \mathrm{AI})$ \\
\hline 1 & Tembalang Selatan VI & Banyumanik & 95 & 90 & 0,26 & 100 \\
2 & Tembalang Selatan IV & Banyumanik & 95 & 80 & 2,37 & 100 \\
3 & Kel. Sendangmulyo & Tembalang & 95 & 80 & 2,37 & 90 \\
4 & Kel. Bulusan & Tembalang & 95 & 90 & 0,26 & 100 \\
5 & Jurang Belimbing & Tembalang & 95 & 90 & 0,26 & 100 \\
\hline
\end{tabular}

Mortalitas kontrol $=(0 \%)$. Mortalitas hasil pengamatan dikoreksi dengan formula Abbott (1925) jika mortalitas kontrol $<20 \% \cdot \chi^{2}$ tabel $(\mathrm{df}=1 ; \alpha=0,05)=3,84$

\section{Validasi Konsentrasi Diagnostik}

Validasi konsentrasi diagnostik ini menggunakan larva uji yang diambil dari selain lima populasi yang telah diuji sebelumnya pada uj utama. Hasil pengujian validasi konsentrasi diagnostik $\mathrm{LC}_{50}=0,0038 \%$, menunjukkan persentase mortalitas yang ditimbulkan kelima populasi berkisar antara $80-90 \%$ dengan nilai $\chi^{2}$ hitung lebih kecil daripada $\chi^{2}$ tabel $(\mathrm{df}=1 ; \alpha=$ $0,05)=3,84$ (Tabel 4).

Pengujian dengan konsentrasi diagnostik $\mathrm{LC}_{50}=0,0038 \%$ terhadap kelima populasi menyebabkan mortalitas $\geq 90 \%$ sebesar $62,79 \%$, sedangkan pengujian dengan konsentrasi $0,225 \%$ AI bahan aktif menyebabkan mortalitas $100 \%$ sebesar $83,33 \%$ sehingga menunjukkan bahwa populasi-populasi yang diuji masih peka terhadap insektisida piretroid sintetik. Konsentrasi diagnostik $\mathrm{LC}_{50}=0,0038 \%$ lebih peka terhadap perubahan kecil frekuensi resistensi dibandingkan dengan konsentrasi 0,225\% AI bahan aktif karena lebih banyak menyebabkan mortalitas $100 \%$. Jika dibandingkan dengan konsentrasi $0,225 \%$ AI bahan aktif, konsentrasi diagnostik $\mathrm{LC}_{50}=$ $0,0038 \%$ mempunyai batasan mortalitas yang jelas, sehingga dengan konsentrasi 0,0038\% diharapkan terjadi mortalitas $95 \%$ sehingga perubahan kecil frekuensi resistensi dapat terdeteksi sedini mungkin.

Hasil pengujian validasi konsentrasi diagnostik menunjukkan bahwa nilai $\chi^{2}$ hitung kelima populasi yang diuji lebih kecil dari nilai $\chi^{2}$ tabel yaitu $(\mathrm{df}=1 ; \alpha=0,05)=3,84$, sehingga konsentrasi diagnostik yang diperoleh sesuai untuk metode monitoring resistensi populasi A. aegypti. Oleh karena itu konsentrasi diagnostik $(0,0038 \%)$ valid sebagai metode monitoring yang efektif terhadap perkembangan resistensi populasi $A$. aegypti di Kecamatan Tembalang.

Hasil penelitian Tarwotjo dkk (2014) menunjukkan bahwa hasil pengujian dengan konsentrasi diagnostik $\left(\mathrm{LC}_{90}=2443,99 \mathrm{ppb}\right)$ terhadap ke sebelas populasi yang diuji menyebabkan mortalitas $\geq 90 \%$ sebesar $51,52 \%$ sehingga lebih efektif untuk monitoring kepekaan populasi Plutella xylostella dibandingkan dengan konsentrasi anjuran 5000 ppb menyebabkan mortalitas $100 \%$ sebesar $72,73 \%$.

\section{KESIMPULAN}

Dari penelitian ini, dapat diambil kesimpu- lan sebagai berikut:

Tingkat kepekaan populasi $A$. aegypti dari lima Kelurahan di Kecamatan Tembalang menunjukkan bahwa Kelurahan Tembalang paling peka terhadap 
insektisida piretroid sintetik dengan nilai $\mathrm{LC}_{50}$ 0,0031\%, sedangkan Kelurahan Tandang kurang peka terhadap insektisida piretroid sintetik dengan nilai $\mathrm{LC}_{50} 0,0043 \%$.

Konsentrasi diagnostik yang diperoleh dari hasil analisis probit yaitu $0,0038 \%$ dan berdasarkan uji $\chi^{2}$ (chi-square kuadrat) konsentrasi diagnostik tersebut valid sebagai metode monitoring resistensi populasi $A$. aegypti terhadap insektisida piretroid sintetik di Kecamatan Tembalang

\section{SARAN}

Dari penelitian yang telah dilakukan, maka penulis memberikan saran sebagai berikut:

Perlu adanya peningkatan pengetahuan yang lebih tentang penggunaan obatnyamuk semprot untuk membasmi nyamuk terutama $A$. aegypti sehingga masyarakat tidak berlebihan dalam penggunaannya yang dapat memicu resistensi.

Penelitian mengenai penetapan konsentrasi diagnostik sebagai metode monitoring resistensi populasi $A$. aegypti terhadap insektisida piretroid sintetik dapat dicoba di Kelurahan lainnya di Kecamatan Tembalang

Penetapan faktor resistensi (FR) harus memperhatikan larva maupun serangga uji yang diambil untuk pengujian, karena dapat dikatakan faktor resistensi (FR) kurang dari 4 itu masih peka, jika larva yang digunakan dari galur murni yang diambil dari hasil rearing tujuh generasi (peka) dan empat generasi (resisten) serta tidak terpapar oleh insektisida selama rearing tersebut.

Perlu adanya penelitian lebih lanjut mengenai penetapan konsentrasi diagnostik sebagai metode monitoring resistensi pada jenis nyamuk dan insektisida dengan bahan aktif yang berbeda.

\section{DAFTAR PUSTAKA}

Achmadi, U. F. 2010. Manajemen Demam Berdarah Berbasis Wilayah. Buletin Jendela Epidemiologi, Vol. 2, Agustus 2010.

Busvine, J.R. 1971. A Critical Review of the Techniques for Testing Insecticides. London: Common-wealth Agriculture Bureaux.

Finney, D.J. 1971. Probit Analysis, 3 rd ed. London: Cambridge Univ Press.
Hallidae, W.R and K.P. Burnham. 1990. Choosing the Optimal Diagnostic Dose for Monitoring Insecticides Resistance. J. Econ Entomol 83: 1151-1159.

Hubert, J.J. 1979. Bioassay. Kendall Hunt Publishing Company, USA.

Kerns, D.L., J.C. Palumbo and T. Tellez. 1998. Resistance of Field Strains of Beet Armyworm (Lepidoptera: Noctuidae) from Arizona and California to Carbamate Insecticides. J. Econ. Entomol. 91: 10381043.

Marcon, P.C.R.G., B.D. Siegfried., T. Spencer and W.D. Hutchinson. 2000. Development of Diagnostig Concentration for Monitoring Bacillus thuringiensis Recistance in European Corn Borer (Lepidoptera: Cerambicidae). J. Econ. Entomol 93: 925930.

Mascarenhas, R.N and D.J. Boethel. 2000 Development of Diagnostic Concentrasion of nsecticide. Resistance Monitoring in Soybean Looper (Lepidoptera: Noctuidae) Larvae Using an Artificial Diet Overley Bioassay. J. Econ Entomol 93: 897-904.

McCutchen, B.F., F.W. Plapp., J.R. Plapp., S.J. Nemec and C. Campanhola. 1989. Development of Diagnostic Monitoring Techniques for Larval Pyrethroid Resistance in Heliothis spp. (Lepidoptera: Noctuidae) in Cotton. J. Econ. Entomol 82: 1056-1507.

Negara, A. 2003. Penggunaan Analisis Probit untuk Pendugaan Tingkat Kepekaan Populasi Spodoptera exigua terhadap Deltametrin di Daerah Istimewa Yogyakarta. Informatika Pertanian. Volume 12.

Shelton, A.M., F.V. Sances., J. Hawley., J. Tang., M. Boune., D. Jungers., H.L. Collins and J. Farias. 2000. Assessment of Insecticide Resistance. After the Outbreak of Diamondback Moth (Lepidoptera: Plutellidae) in California in 1997. J. Econ. Entomol 93: 931-936.

Suhendro., L. Nainggolan., K. Chen., H. T. Pohan. 2006. Demam Berdarah Dengue In: Aru W. Sudoyo, Bambang Setiyohadi, Idrus Alwi, Marcellus Simadibrata K., Siti Setiati. Editors: Buku Ajar Ilmu Penyakit Dalam. Jilid III edisi IV. Jakarta: Pusat Penerbitan 
Departemen Ilmu Penyakit Dalam Fakultas Kedokteran Universitas Indonesia. P.17311735.

Tarwotjo, U., J. Situmorang., R.C.H. Soesilohadi dan E. Martono. 2014. Monitoring Resistensi Populasi Plutella xylostella, L terhadap Residu Emamektin Benzoat di Sentra Produksi Tanaman Kubis Propinsi Jawa Tengah. J Manusia dan Lingkungan, Vol 21 No 2: 202-212.

Trisyono and M.E. Whalon. 1999. Toxicity of Neem Apllied Alone and in Combination with Bacillus thuringiensis to Colorado Potato Beetle (Coleoptera: Chrysomelidae). J. Econ Entomol 92: 1281-1288.

Ullah, S and Sarfraz, A.S. 2017. Toxicity of insecticides, cross-resistance and stability of chlorfenapyr resistance in different strains of Oxycarenus hyalinipennis Costa (Hemiptera: Lygaeidae). J. Econ Entomol 99: 132-136.

Umniyati, S.R. 1990. Analisa Probit secara Aritmatis untuk Pengujian Toksisitas Insektisida terhadap Serangga. Yogyakarta: FK UGM.
Untung, K. 2004. Manajemen Resistensi Pestisida sebagai Penerapan Pegelolaan Hama Terpadu. Makalah Disampaikan pada Seminar Nasional Manajemen Resistensi Pestisida dalam Penerapan Pengelolaan Hama Terpadu 24-25 Februari Yogyakarta.

Widyastuti, B. 1999. Pengaruh Logam Berat Tembaga (Cu) terhadap Mortalitas dan Pertumbuhan Berat Badan Larva Artemia. Semarang: FMIPA UNDIP.

Winteringham, F.P.W. 1969. FAO international Collaborative Programme for the Development Standardized test for Resistance of Agricultural Pests to Pesticides. FAO Plant Prot. Bull. 7:73-75.

Yuniarti, R.A dan T.B. Damar. 2008. Efikasi kombinasi Bacillus thuringiensis Israelensis dan mesocyclops aspericornis sebagai pengendali hayati Aedes aegypti di gentong air. Buletin Penelitian Kesehatan 8: 26-32. 